\title{
Effects of Dietary Wheat Middlings and Supplemental Phosphorus on Growth of Turbot, Scophthalmus maximus Linnaeus, 1758
}

\section{Bonkalite ve İlave Fosforun Kalkan Scophthalmus maximus Linnaeus, 1758 Büyümesi Üzerine Etkileri}

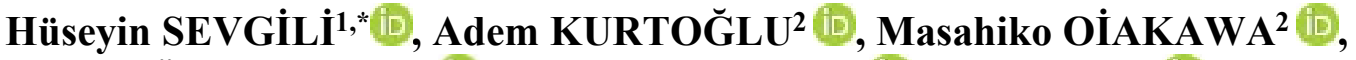 \\ Özgür AKTAŞ ${ }^{2}$, Salih KOCAKAYA ${ }^{2}$ (D) , Faruk PAK ${ }^{2}$ \\ 'Department of Aquaculture, Isparta University of Applied Sciences, Çünür, Isparta, Turkey \\ ${ }^{2}$ Mediterranean Fisheries Research Production and Training Institute, Antalya, Turkey
}

\begin{abstract}
This study was carried out to determine the effects of replacement of wheat flour with wheat middling (WM) and supplemental phosphorus at a level of $1 \%$ on growth and nutrient utilization, whole body, fillet, viscera and liver proximate compositions in turbot, (Scophthalmus maximus Linnaeus, 1758). The control diet was based on a mixture of three fish meals and whole wheat flour. Fish with an average initial weight of $266.67 \pm 0.72 \mathrm{~g}$ were fed experimental diets for 9 weeks. Each treatment was tried in four replicates. At the end of the experiment, there were no significant effects of the treatment on growth rate, nutrient utilization parameters such as feed intake, feed conversion ratio, protein efficiency rate, nitrogen, lipid and energy gains and retentions, hepato-somatic index, viscero-somatic index, condition factor, whole body (except dry matter which was significantly lower in $\mathrm{P}$ added diet than the control) and organ nutrient compositions ( $\mathrm{P}>0.05)$. The findings suggest that WM can totally replace wheat flour and there is a tendency of a positive contribution of dietary $\mathrm{P}$ supplementation on the response variables.
\end{abstract}

Keywords: Turbot, nutrition, wheat middling, phosphorus

Article Info

Received: 05 July 2021

Revised: 13 July 2021

Accepted: 13 July 2021

(corresponding author)

E-mail: husevgili@yahoo.com

To cite this article: Sevgili, H., Kurtoğlu, A., Oiakawa, M., Aktaş, Ö., Kocakaya, S., Pak, F., (2021). Effects of Dietary Wheat Middlings and Supplemental Phosphorus on Growth of Turbot, Scophthalmus maximus Linnaeus, 1758, Turkish Journal of Maritime and Marine Science 7(2): 128-137. doi: 10.52998/trjmms.962181. 


\section{ÖZET}

Bu çalışma kalkan yemlerinde (Scophthalmus maximus Linnaeus, 1758) buğday unu yerine bonkalite kullanımı ve \%1 düzeyinde ilave fosfor ilavesinin büyüme, yemden yararlanma, tüm vücut, fileto, iç organlar ve karaciğer besin maddesi kompozisyonları üzerine etkilerini belirlemek üzere yürütülmüştür. Kontrol yemi üç farklı balık unu karşımı ile buğday unu esaslı olarak hazırlanmıştır. Araştırmada, ortalama başlangıç ağırlığı of $266.67 \pm 0.72 \mathrm{~g}$ olan balıklar 9 hafta boyunca deneme yemleri ile beslenmişlerdir. Her bir deneme grubu dört tekerrürlü olarak denenmiştir. Deneme sonunda, deneme grupları arasında büyüme oranı, yem tüketimi, yemden yararlanma, protein etkinlik oran1, azot, lipit ve enerji değerlendirme parametreleri, hepatosomatik indeks, iç organlar indeksi, kondisyon faktörü, vücut (fosfor ilaveli grupta kontrolden daha düşük kuru madde hariç) ve organ besin kompozisyonları bakımından herhangi bir fark bulunmamıştır ( $\mathrm{P}>0.05)$. Araştırma bulguları, kalkan yemlerinde bonkalitenin buğday ununun tamamı yerine kullanılabileceğini göstermiştir. Ayrıca, fosfor ilavesinin ele alınan değişkenler bakımından pozitif yönde etkileme eğilimine sahip olduğunu ortaya koymuştur.

Anahtar sözcükler: Kalkan, balık besleme, bonkalite, fosfor

\section{INTRODUCTION}

Whole wheat or wheat flour are widely used in fish diets as a carbohydrate source (Hertrampf and Piedad-Pascual, 2000; NRC, 2011). Wheat middlings is a by-product of wheat milling, obtained while wheat is processed to flour, also known as wheat pollard and generally contains higher protein, $\mathrm{P}$ and cellulose than flour (Cromwell et al., 2000, Cheng and Hardy, 2002 Hertrampf and Piedad-Pascual, 2000). Although wheat middling is cheaper than the meal, the effects of its dietary use instead of wheat meal on growth and feed utilization in aquatic species have not been adequately studied. Available studies on fish species including rainbow trout (Oncorhynchus mykiss), Atlantic salmon (Salmo salar) and silver catfish (Rhamdia quelen) suggest that wheat middling is a valuable carbohydrate source when included at adequate levels (Hilton and Silinger, 1983; Hughes, 1990; Pessini et al., 2019).

Phosphorus (P) is an essential element for fish and many symptoms such as poor growth, skeletal deformities, deteriorated mineral metabolism and increased lipid accumulation occurs when dietary concentrations are insufficient (NRC, 2011). However, excessive dietary $\mathrm{P}$ levels above the requirements are not deposited in the fish body and excreted to the environment via faeces and urine, which may lead to eutrophication (NRC, 2011). Fish meal is used as the main protein source in fish feeds and supplies substantial amounts of other nutrients including P. Although a report related to dietary $P$ deficiency has not been encountered in turbot fed diets with commonly available ingredients (Nagel et al., 2012, Burel et al., 2000), there is no specific attempt to dealt with dietary $\mathrm{P}$ supplementation to fish meal-based diet in turbot. This could be of significance since $\mathrm{P}$ is present in fish meal in complex $\mathrm{Ca}$ hydroxyapatite-formation that reduces digestions of $\mathrm{P}$ and other minerals by fish (Satoh et al., 1987, Albrektsen et al., 2009). Therefore some authors suggest a dietary supplementation to fish meal-based diets (Albrektsen et al., 2009), but if this is a necessity in turbot diets based on fish meal or not remains unknown. Turbot is considered an alternative fish species for diversification of the finfish aquaculture sector of Turkey.

Therefore this study was planned to determine the effects of supplemental dietary phosphorus with and replacement of wheat meal with middling in fish meal-based diets on growth performance, whole body, and organ proximate compositions of turbot. 


\section{MATERIAL AND METHOD}

\subsection{Fish and Rearing System}

The experiment was carried out at the Beymelek Unit of Mediterranean Fisheries Research Production and Training Institute, Antalya, Turkey. Juvenile turbot were transferred from Central Fisheries Research Institute, Trabzon, Turkey. Fish were randomly allocated to 12 tanks $(50 \times 70 \times 40 \mathrm{~cm})$ with $100 \mathrm{~L}$ water holding capacity and adapted for three weeks before the commencement of the study. Up to the experiment, fish were fed a commercial diet (K1lıç Deniz Ürünleri, Muğla, Turkey) with 57\% protein and $9 \%$ lipid. At the start of the experiment, the number of fish in each tank was reduced to eight fish. The average initial weight was $266.67 \pm 0.72 \mathrm{~g}$. Brackish water treated with UV was supplied to each tank at a flow rate of $2.5 \mathrm{~L} / \mathrm{min}$. Fish were held in an indoor system allowing natural light to enter and subjected to natural photoperiod between 16.10.2009 and 18.12.2009. Water temperature, dissolved oxygen, $\mathrm{pH}$ and salinity were monitored daily with a hand DO meter and $\mathrm{pH}$ meter (YSI Model 55 and 63, YSI Inc., Yellowsprings, OH, USA) and were $17.66 \pm 0.03{ }^{\circ} \mathrm{C}, 7.28 \pm 0.03 \mathrm{mg} / \mathrm{L}, 7.61$ \pm 0.01 and $8.27 \pm 0.01 \mathrm{~g} / \mathrm{L}$ respectively. During the study, fish in each tank were bulk weighed at three-week-intervals and at end of the experiment after about one day starvation period. Experimental fish were fed their respective diets until apparent satiation by hand twice a day for 9 weeks. At the beginning of the experiment, a total of ten fish were sampled for the determination of initial body composition whereas, at the end of the experiment, all eight fish were sampled from each tank through overdose ethylene glycol monophenyl ether, four fish were pooled and used for determination of final proximate composition, and the remaining four were used for determination of organosomatic indices.

\subsection{Experimental Diets}

Three diets were formulated based on a dry matter basis using the linear method in Winfeed 2.8 (Winfeed Ltd., Cambridge, UK). Fish meal (a mixture of three different fish meal source) based control diet was formulated with wheat flour and without supplemental phosphorus (Table 1).

Table 1. Ingredient and proximate composition of experimental diets

\begin{tabular}{|c|c|c|c|}
\hline & Control & $\mathrm{P}$ & WM \\
\hline Fish meal mixture $^{1}$ & 65.42 & 65.63 & 63.16 \\
\hline Wheat flour & 21.66 & 20.46 & \\
\hline Wheat middling & & - & 24.76 \\
\hline Wheat gluten & 5 & 5 & 5 \\
\hline Fish oil & 6.77 & 6.76 & 5.93 \\
\hline Monocalcium phosphate & - & 1.0 & - \\
\hline Vitamin $^{2}$ & 0.25 & 0.25 & 0.25 \\
\hline Mineral $^{3}$ & 0.1 & 0.1 & 0.1 \\
\hline Cholin chloride $^{4}$ & 0.2 & 0.2 & 0.2 \\
\hline $\mathrm{CMC}^{5}$ & 0.5 & 0.5 & 0.5 \\
\hline Vitamin $C^{6}$ & 0.1 & 0.1 & 0.1 \\
\hline \multicolumn{4}{|c|}{ Nutrient levels (dry matter basis) } \\
\hline Dry matter & 90.8 & 91.1 & 91.7 \\
\hline Protein & 54.9 & 54.5 & 53.6 \\
\hline Lipid & 13.5 & 13.3 & 13.7 \\
\hline Ash & 9.7 & 9.7 & 10.5 \\
\hline Gross energy & 22.1 & 22.0 & 21.9 \\
\hline $\mathrm{P} / \mathrm{E}\left(\mathrm{g}\right.$ CP MJ GE) ${ }^{7}$ & 24.8 & 24.7 & 24.4 \\
\hline
\end{tabular}

$1 \longdiv { 3 3 . 3 \% \text { Danish fish meal, 33.3\% Peruvian fish meal, and } }$ $33.4 \%$ local anchovy meal.

${ }^{2}$ Vitamin premix included (per kg diet): vitamin A, 25000 IU as acetate; vitamin $\mathrm{D}_{3}, 3000 \mathrm{IU}$; vitamin E, $400 \mathrm{mg}$ as DL- $\alpha$-tocopheryl acetate; vitamin $\mathrm{K}_{3}, 15 \mathrm{mg}$ as menadione sodium bisulfite; vitamin $\mathrm{B}_{1}, 40 \mathrm{mg}$ as thiamine mononitrate; vitamin $\mathrm{B}_{2}, 50 \mathrm{mg}$ as $\mathrm{FMN}$ sodium salt; vitamin $\mathrm{B}_{6}, 40 \mathrm{mg}$ as pyridoxine hydrochloride; vitamin $\mathrm{B}_{12}, 0.02 \mathrm{mg}$; vitamin $\mathrm{C}, 350 \mathrm{mg}$ as L-ascorbic acid; niacin, $400 \mathrm{mg}$ as niacinamide; inositol, $450 \mathrm{mg}$; Dpantothenic acid, $100 \mathrm{mg}$ as calcium DL-pantothenate; biotin, $1.8 \mathrm{mg}$ as d-biotin; folic acid, $10 \mathrm{mg}$; antioxidant, $250 \mathrm{mg}$ as BHT.

${ }^{3}$ Mineral premix included (g per $\mathrm{kg}$ diet): copper 6 , as copper sulphate; iron, 30 as iron sulphate; manganese, 60 as manganese oxide; zinc, 75 as zinc oxide; magnesium, 0.15 as magnesium oxide; cobalt, 5 as microgranule cobalt $5 \%$; iodine, 2 as microgranule iodine $10 \%$; selenium, 0.4 as microgranule selenium $4.5 \%$.

${ }^{4}$ DSM nutritional products Ltd., Switzerland.

${ }^{5}$ Uğur Cellulose Chemicals, Aydın, Turkey.

${ }^{6}$ Ascorvet, Vetaş, İstanbul, Turkey.

${ }^{7}$ Crude protein to Gross energy ratio. 
In the second diet, wheat flour was totally replaced with wheat middling (WM) whereas in the third diet exogenous phosphorus as monocalcium phosphate was added as an inorganic phosphorus source at a level of $1 \%(\mathrm{P})$ considering the results of Albrektsen et al. (2009). Before diet preparation, all the ingredients were ground with a hammer mill with an $800 \mu \mathrm{m}$ screen (Kocamaz Machine, Model KT-20C, İzmir, Turkey), weighed at predetermined levels, thoroughly mixed and then the mixtures were pelleted using a pelleting machine (with a 9-mm die) without steam, packed in plastic bags and stored at $+4{ }^{\circ} \mathrm{C}$ until use.

\subsection{Calculation and Chemical Analysis}

Growth and feed utilization variables, such as weight gain (WG), daily growth coefficient (DGC), feed intake (FI), feed conversion ratio (FCR), condition factor (CF), nutrient intakes, gains and retentions, protein efficiency ratio (PER) and $\mathrm{N}$ loss, and organ indices were calculated by the formulas provided in footnotes of the tables.

Fish samples were stored at $-20{ }^{\circ} \mathrm{C}$ until analysis. Before analysis, they were thawed in a refrigerator overnight and then homogenized using a kitchen meat chopper (Tefal Le Hachoir 1500, France). Proximate analysis, except crude lipid, of experimental diets and fish were performed according to the methods of (AOAC (1990)): dry matter at $104{ }^{\circ} \mathrm{C}$ till constant weight, ash content by incineration in a muffle furnace at $600^{\circ} \mathrm{C}$ for $2 \mathrm{~h}$; crude protein $(\mathrm{N} \times 6.25)$ by the Kjeldhal method after acid digestion. Lipid was determined with ether extraction using an automatic extraction system (ANKOMXT15 Extractor, ANKOM Technology, Macedon, USA). Gross energy values of feeds and fish samples were calculated using conversion factors of $39.5,23.6$, and $17.2 \mathrm{MJ} \mathrm{kg}^{-1}$ for fat, protein, and carbohydrate, respectively.

\subsection{Statistical Analysis}

The normality and homogeneity of the data were checked by the Shapiro-Wilk test and Bartlett's test, respectively. All percentage values were arcsine transformed before analysis of variance. One-way analysis of variance (ANOVA) followed by Dunnett's test considering wheat meal diet as the control was used to detect the significant differences between treatments. A significance level of $\mathrm{P}<0.05$ was used.

\section{RESULTS}

All diets were well accepted by the fish and there was no mortality due to the treatments in the present study.

Growth rate, FCR, PER, VFI, and organ indices including CF, VSI and HSI of turbot fed the experimental diets were comparable (Table 2). Whole-body dry matter levels of fish maintained on $\mathrm{P}$ were significantly higher than the control $(\mathrm{P}<0.05)$.

However, there were no significant differences among the treatments in terms of other proximate parameters (Table 3). Dry matter, protein, ash, gross energy and crude lipid levels of fillet, viscera and liver of fish fed the experimental diets were also not significantly different $(\mathrm{P}>0.05)$.

Nutrient utilization variables of fish such as nitrogen, lipid and energy gains and retentions were not significantly affected by dietary treatments (Table 4) $(\mathrm{P}>0.05)$. 
Table 2. Growth and feed utilization of turbot fed diets wheat middling and supplemental $P$

\begin{tabular}{llll}
\hline Variables & Control & With Phosphorus & With Wheat middling \\
\hline IW (g/fish) & $266.7 \pm 0.9$ & $266.3 \pm 1.6$ & $267.0 \pm 1.5$ \\
FW (g/fish) & $413.1 \pm 11.8$ & $423.1 \pm 3.8$ & $405.9 \pm 14.2$ \\
DGC (\%. day) & $1.60 \pm 0.11$ & $1.70 \pm 0.03$ & $1.53 \pm 0.12$ \\
VFI (g/MBW $0.8 /$ day) & $4.81 \pm 0.12$ & $5.12 \pm 0.13$ & $4.97 \pm 0.09$ \\
FCR & $0.87 \pm 0.05$ & $0.86 \pm 0.04$ & $0.95 \pm 0.07$ \\
PER & $2.12 \pm 0.12$ & $2.17 \pm 0.09$ & $2.00 \pm 0.15$ \\
CF & $1.44 \pm 0.02$ & $1.43 \pm 0.06$ & $1.44 \pm 0.03$ \\
VSI (\%) & $4.57 \pm 0.12$ & $4.63 \pm 0.19$ & $4.57 \pm 0.12$ \\
HSI (\%) & $1.34 \pm 0.07$ & $1.34 \pm 0.07$ & $1.27 \pm 0.05$ \\
\hline
\end{tabular}

IW; Initial weight, FW; final weight, $\mathrm{MBW}=$ metabolic body weight; $\mathrm{CF}=$ condition factor; $\mathrm{DGC}=$ daily growth coefficient; FCR = feed conversion ratio; FW = final weight; HSI = hepato somatic index; $\mathrm{PER}=$ protein retention efficiency; VFI = voluntary feed intake; VSI = viscera somatic index.

Mean values $(n=4)$ and pooled standard error of the mean (SE) are presented for each variable obtained after the 9week experimental duration. No significant differences were detected between the treatments following the 9 weeks $(P>0.05) . \mathrm{VFI}=($ dry matter intake/ABW $) / \mathrm{d} . \mathrm{MBW}=$ Geometrci mean $(\mathrm{IW}+\mathrm{FW})^{0.8} . \mathrm{DGC}=([\mathrm{FW} 1 / 3-\mathrm{IW} 1 / 3] / \mathrm{d})$ $\times 100 . \mathrm{FCR}=$ dry matter intake/weight gain. $\mathrm{PER}=$ weight gain/protein fed $\mathrm{CF}=($ average weight $/$ standard length3 $)$ $\times 100 . \mathrm{VSI}=($ visceral weight/body weight $) \times 100 . \mathrm{HSI}=($ liver weight $/$ body weight $) \times 100$.

Table 3. Whole-body, fillet, liver, and intestine proximate compositions of turbot fed diets with wheat middling and supplemental $\mathrm{P}$

\begin{tabular}{|c|c|c|c|c|}
\hline & & Control & With Phosphorus & With Wheat middling \\
\hline Whole-body & Initial & & & \\
\hline Dry matter & 22.5 & $24.32 \pm 0.21$ & $23.77 \pm 0.01 *$ & $23.92 \pm 0.13$ \\
\hline Gross energy & 4.12 & $4.73 \pm 0.06$ & $4.78 \pm 0.04$ & $4.87 \pm 0.05$ \\
\hline Crude ash & 4.60 & $4.64 \pm 0.23$ & $4.51 \pm 0.10$ & $4.24 \pm 0.04$ \\
\hline Crude protein & 15.25 & $16.00 \pm 0.16$ & $16.15 \pm 0.14$ & $16.24 \pm 0.20$ \\
\hline Crude lipid & 1.28 & $2.37 \pm 0.15$ & $2.40 \pm 0.03$ & $2.59 \pm 0.10$ \\
\hline \multicolumn{5}{|l|}{ Fillet } \\
\hline Dry matter & & $23.98 \pm 0.46$ & $24.06 \pm 0.56$ & $23.64 \pm 0.32$ \\
\hline Gross energy & & $5.45 \pm 0.18$ & $5.54 \pm 0.14$ & $5.36 \pm 0.05$ \\
\hline Crude ash & & $2.07 \pm 0.05$ & $1.90 \pm 0.08$ & $1.91 \pm 0.29$ \\
\hline Crude protein & & $19.88 \pm 0.36$ & $20.10 \pm 0.37$ & $20.02 \pm 0.16$ \\
\hline Crude lipid & & $1.88 \pm 0.28$ & $1.97 \pm 0.15$ & $1.56 \pm 0.06$ \\
\hline \multicolumn{5}{|l|}{ Viscera } \\
\hline Dry matter & & $18.37 \pm 0.65$ & $17.76 \pm 0.25$ & $17.26 \pm 0.20$ \\
\hline Gross energy & & $3.80 \pm 0.15$ & $3.68 \pm 0.07$ & $3.61 \pm 0.04$ \\
\hline Crude ash & & $1.08 \pm 0.03$ & $1.11 \pm 0.02$ & $1.03 \pm 0.02$ \\
\hline Crude protein & & $14.16 \pm 0.54$ & $13.75 \pm 0.33$ & $13.46 \pm 0.19$ \\
\hline Crude lipid & & $1.13 \pm 0.09$ & $1.07 \pm 0.03$ & $1.05 \pm 0.05$ \\
\hline \multicolumn{5}{|l|}{ Liver } \\
\hline Dry matter & & $29.23 \pm 2.42$ & $28.98 \pm 0.58$ & $28.07 \pm 0.54$ \\
\hline Gross energy & & $7.58 \pm 0.98$ & $7.26 \pm 0.13$ & $6.80 \pm 0.17$ \\
\hline Crude protein & & $12.09 \pm 0.48$ & $11.31 \pm 0.42$ & $11.91 \pm 0.27$ \\
\hline Crude lipid & & $11.93 \pm 2.65$ & $11.60 \pm 0.58$ & $10.08 \pm 0.39$ \\
\hline
\end{tabular}

Mean values $(n=4)$ and pooled standard error of the mean (SE) are presented for each variable obtained after the 9-week experimental duration. No significant differences, except whole body dry matter which only differed in P-added treatment from the control, were detected between the treatments following the 9 weeks $(P>0.05)$. 
Table 4. Nutrient utilization performance of turbot fed experimental diets

\begin{tabular}{|c|c|c|c|}
\hline & Control & With Phosphorus & $\begin{array}{l}\text { With Wheat } \\
\text { middling }\end{array}$ \\
\hline \multicolumn{4}{|l|}{ Nitrogen } \\
\hline Intake (g/kg MBW ${ }^{0.8} /$ day) & $0.42 \pm 0.01$ & $0.44 \pm 0.01$ & $0.43 \pm 0.01$ \\
\hline Gain (g/kg MBW $0.8 /$ day) & $0.16 \pm 0.01$ & $0.16 \pm 0.00$ & $0.14 \pm 0.01$ \\
\hline Retention $(\%)$ & $36.79 \pm 1.82$ & $36.49 \pm 1.41$ & $33.31 \pm 2.30$ \\
\hline Loss (g/ kg WG) & $48.39 \pm 4.00$ & $47.21 \pm 3.04$ & $54.34 \pm 5.88$ \\
\hline \multicolumn{4}{|l|}{ Lipid } \\
\hline Intake (g/kg MBW ${ }^{0.8} /$ day) & $0.65 \pm 0.02$ & $0.70 \pm 0.02$ & $0.68 \pm 0.01$ \\
\hline Gain (g/kg MBW $0.8 /$ day) & $0.24 \pm 0.03$ & $0.26 \pm 0.01$ & $0.27 \pm 0.02$ \\
\hline Retention $(\%)$ & $37.35 \pm 3.27$ & $36.78 \pm 1.74$ & $40.21 \pm 3.57$ \\
\hline \multicolumn{4}{|l|}{ Energy } \\
\hline Intake $\left(\mathrm{kJ} / \mathrm{kgMBW}^{0.8} /\right.$ day $)$ & $106.4 \pm 2.7$ & $112.3 \pm 2.9$ & $109.6 \pm 1.9$ \\
\hline Gain (kJ/kgMBW $0.8 /$ day) & $32.70 \pm 1.98$ & $35.13 \pm 0.58$ & $33.76 \pm 2.03$ \\
\hline Retention (\%) & $30.67 \pm 1.13$ & $31.35 \pm 1.05$ & $30.83 \pm 1.89$ \\
\hline
\end{tabular}

\section{DISCUSSIONS}

Effects of dietary inclusion of wheat middling in fish have been attracted little attention although it is widely used in commercial diets (Hertrampf and Piedad-Pascual, 2000). Existing data in terms of nutritional evaluation are concentrated mostly on its nutrient digestibility values. Vidal et al. (2017) evaluated nutrient digestibility of wheat and wheat by-products including wheat middling in diets of tilapia, Oreochromis niloticus. These researchers recorded lower nutrient digestibility coefficients of wheat middling for dry matter, protein, energy, and amino acid compared with whole wheat, wheat bran, and wheat germ, which was attributed to its higher fibre contents. Although very good energy and protein digestibility values (slightly lower than fish meal) of wheat middling were reported for sunshine bass (Morone chrysops $9 \times$ M. saxatilis ${ }^{\widehat{ }}$ ) (Rawles and Gatlin, 2000), apparent dry matter and energy digestibilities were inferior for tilapia (Guimaraes et al., 2008), red drum (Sciaenops ocellatus) (McGoogan and Reigh, 1996), common carp (Cyprinus carpio) (Fagbenro, 1999), coho salmon (Oncorhynchus kistuch) and rainbow trout (Sugiura et al., 1998, Cheng and Hardy, 2002). It appears that high cellulose contents in wheat middling reduces the availability of dry matter and energy to fish. However, its protein appears to be highly digestible considering that the abovementioned studies showed that average protein availability was over $80 \%$. From these observations, one can expect that the inclusion of wheat middling to turbot diets at about $25 \%$, as it was in the present study, could lead to a deterioration in growth and nutrient utilization performance. Atlantic salmon grew equally when fed diets with wheat middling or triticale as the main carbohydrate sources (Hughes, 1990). However, when the dietary wheat middling level was reduced from 32.7 to $16.4 \%$ with a replacement of wheat bran in diets of rainbow trout, the final average weight of fish significantly increased (Hilton and Slinger, 1983). Replacement of corn flour with wheat middlings in diets of juvenile silver catfish resulted in comparable growth performance (Pessini et al., 2019). Although numerically inferior growth rate, FCR and PER values in fish reared on WM diet than those on the control were the case in the present study but these differences were not significant $(\mathrm{P}>0.05)$, being within the range of those reported previously for turbot (Sevgili et al., 2015a; 2015b; Kurtoğlu et al., 2019). 
Furthermore, the whole body, fillet, viscera, and liver proximate compositions, as well as nitrogen, lipid and energy utilization variables of WM fed fish, were comparable to those on the control diet. This suggests that wheat middling is on par with wheat flour in terms of nutritional values for turbot and can be used in place of wheat flour. Care should be exercised, however, in using WM in turbot diets above $25 \%$ because high dietary inclusion rates could result in growth deteriorations in terrestrial monogastric animals such as pig (Cromwell et al., 2000). Moreover, WM is a highly variable ingredient in terms of nutritional compositions (Cromwell et al., 2000), which could place it in an ingredient class of prudent use in turbot diets.

Dietary $\mathrm{P}$ requirements of turbot have not been determined but other flatfishes such as Japanese flounder (Paralichthys olivaceus) are reported to require a dietary level between 0.45 - and $1.65 \%$ (Wang et al., 2005, Uyan et al., 2007, Choi et al., 2005). Japanese flounder fed dietary P deficient diets showed poor growth, FCR, low whole body ash and phosphorus, opercula malformations, deformed head, spongy vertebral bones, and high whole-body lipid (Uyan et al., 2007, Wang et al., 2005, Choi et al., 2005). Although fish meal is a highly rich source of $\mathrm{P}$, sometimes supplemental $\mathrm{P}$ can be essential. For instance, Atlantic salmon fed a diet based on fish meal from blue whiting which was devoid of dietary inorganic $\mathrm{P}$ supplementations were suffered from dietary $\mathrm{P}$ deficiency by showing reduced growth, bone mineralization, and lipid accumulation (Fjelldal et al., 2016). So far, no specific attempt to investigate the effects of dietary $\mathrm{P}$ addition into turbot diets based on fish meal has been done. However, a study conducted in turbot reared in the recirculation system has suggested that a concentration of waterborne orthophosphate of about $25 \mathrm{mg} / \mathrm{L}$ could improve some performance variables including SGR and protein retention (van Bussel et al., 2013). In the present experiment, dietary $\mathrm{P}$ addition at $1 \%$ did not change fish performance variables, HSI and VSI, although numerically some improvements in growth rate, together with whole-body proximate compositions except dry matter which was significantly lower than the control were recorded. The control diet had a sufficient amount of $\mathrm{P}$ to meet dietary requirements, which may be due to the incorporation of three different sources of fish meal. Indeed, the use of a mixture of fish meal rather than a single source can substantially change the levels of dietary phosphorus levels and subsequent mass balance values including whole body intakes, gains, retentions, and losses to the environment (Sevgili et al., 2015b). Indeed, fish meal with high $\mathrm{P}$ contents lost more $\mathrm{P}$ to the environment in that study even though it is now known whether other fish meal sources were sufficient in terms of meeting the dietary $\mathrm{P}$ requirement of turbot (Sevgili et al., 2015b). However, as long as a mixture of fish meal sources is included at levels around presently used, a dietary $P$ deficiency will be never the case or no dietary $\mathrm{P}$ addition will be required as judged from the results of the current study. However, a luxury use of three fish meal in turbot or other aquaculture fish diets at about $60 \%$ as in the present study will not be possible considering the finite production of global fish meal regardless of species or origin. The inclusions of plant protein sources instead of fish meal especially at increased levels generally necessitate supplementing either exogenous dietary phosphorus or phytase and/or organic acids in fish (NRC, 2011).

Briefly, wheat flour can be replaced in growing turbot diets without deterioration of growth, feed utilization, and whole-body or organ biochemical compositions. Cost estimation of the experimental diets revealed that using WM in place of flour reduced the diet price by about $6 \%$. Although there was no significant reduction in the cost of feeding with WM for a unit of fish production over the control diet, the present results give extra room in the selection of cereal products in turbot diets. Yet, variabilities in the nutrient compositions of WM should be taken into consideration when using in aquaculture diets. No positive effect of $\mathrm{P}$ supplementation into turbot diets with a mixture of fish meals as the main protein source is observed. Further studies are required to determine dietary $\mathrm{P}$ requirements at different sizes of turbot for optimization of dietary levels. 


\section{ACKNOWLEDGEMENTS}

Senior scientists G. Nezaki and N. Takeno and other project members are gratefully acknowledged for their valuable contributions during the study.

\section{AUTHORSHIP CONTRIBUTION STATEMENT}

Hüseyin SEVGILI: Conceptualization, Methodology, Validation, Formal Analysis, Resources, Writing - Original Draft and Editing, Data Curation, Statistical Analysis Adem KURTOĞLU: Conceptualization, Methodology, Manuscript Writing-Review and Editing, Data Curation Masahiro OİKAWA: Conceptualization, Methodology, Writing and Editing Manuscript Özgür AKTAŞ: Methodology, Nutrient Analysis, Statistical Analysis, Writing and Editing Manuscript Salih KOCAKAYA: Methodology, Data Curation, Writing and Editing Manuscript Faruk PAK: Methodology, Nutrient Analysis, Statistical Analysis, Writing and Editing Manuscript.

\section{CONFLICT OF INTERESTS}

The author(s) declare that for this article they have no actual, potential or perceived conflict of interests.

\section{ETHICS COMMITTEE PERMISSION}

Author(s) declare that this study was conducted in accordance with ethics committee procedures of human or animal experiments.

\section{FUNDING}

This work was supported/funded by a collaborative project between the Japan International Cooperation Agency and General Directorate of Agricultural Production, Turkey titled "Flatfish Culture Project".

\section{ORCID IDs}

Hüseyin SEVGİLI:

(iD) https://orcid.org/0000-0001-8274-7391

Adem KURTOĞLU:

(iD) https://orcid.org/0000-0002-7615-7800

Masahiro OİKAWA:

(iD) https://orcid.org/0000-0001-6511-9414

Özgür AKTAȘ:

(iD) https://orcid.org/0000-0002-3175-2251

Salih KOCAKAYA:

(iD https://orcid.org/0000-0002-2585-2862

Faruk PAK:

(D) https://orcid.org/0000-0003-4191-6173

\section{REFERENCES}

Albrektsen, S., Hope, B., Aksnes, A., (2009). Phosphorous (P) deficiency due to low $\mathrm{P}$ availability in fishmeal produced from blue whiting (Micromesistius poutassou) in feed for under-yearling Atlantic salmon (Salmo salar) smolt. Aquaculture, 296, 318-328. doi: https://doi.org/10.1016/j.aquaculture.2009.08.033

AOAC (1990). Official Methods of Analysis, Association of Official Analytical Chemists, Arlington, VA.

Burel, C., Boujard, T., Kaushik, S.J., Boeuf, G., Van Der Geyten, S., Mol, K.A., Kühn, E.R., Quinsac, A., Krouti, M., Ribaillier, D., (2000). Potential of plantprotein sources as fish meal substitutes in diets for turbot (Psetta maxima): growth, nutrient utilisation and thyroid status. Aquaculture, 188, 363-382. doi: https://doi.org/10.1016/S0044-8486(00)00342-2

Cheng, Z., Hardy, R., (2002). Effect of microbial phytase on apparent nutrient digestibility of barley, canola meal, wheat and wheat middlings, measured in vivo using rainbow trout (Oncorhynchus mykiss). Aquaculture Nutrition, 8, 271-277. doi: https://doi.org/10.1046/j.1365-2095.2002.00219.x

Choi, S.-M., Kim, K.-W., Kang, Y.-J., Wang, X., Kim, J.-W., Yoo, G.-Y. Bai, S.C., (2005). Reevaluation of the phosphorus requirement of juvenile olive flounder Pavalichfhys olivaceus and the bioavailability of various inorganic phosphorus sources. Journal of the World Aquaculture Society, 36, 217-222. doi: https://doi.org/10.1111/j.1749-7345.2005.tb00388.x

Cromwell, G., Cline, T., Crenshaw, J., Crenshaw, T., Easter, R., Ewan, R., Hamilton, C., Hill, G., Lewis, A., Mahan, D., (2000). Variability among sources and laboratories in analyses of wheat middlings. NCR-42 Committee on Swine Nutrition. Journal of animal science, 78, 2652-2658. doi: https://doi.org/10.2527/2000.78102652x 
Fagbenro, O., (1999). Apparent digestibility of various cereal grain by-products in common carp diets. Aquaculture International, 7, 277-281. doi: https://doi.org/10.1023/A:1009285214776

Fjelldal, P., Hansen, T., Lock, E.J., Wargelius, A., Fraser, T., Sambraus, F., El-Mowafi, A., Albrektsen, S., Waagbo, R., Ornsrud, R., (2016). Increased dietary phosphorous prevents vertebral deformities in triploid Atlantic salmon (Salmo salar L.). Aquaculture nutrition, 22, 72-90. doi: https://doi.org/10.1111/anu.12238

Guimaraes, I.G., Pezzato, L.E., Barros, M.M., Tachibana, L., (2008). Nutrient Digestibility of cereal grain products and by-products in extruded diets for Nile tilapia. Journal of the World Aquaculture Society, 39, 781-789. doi: https://doi.org/10.1111/j.17497345.2008.00214.x

Hertrampf, J. W., Piedad-Pascual, F., (2000). Wheat and wheat by-products. In Handbook on ingredients for aquaculture feeds (pp. 531-542). Springer, Dordrecht.

Hilton, J. W., Slinger, S. J., (1983). Effect of wheat bran replacement of wheat middlings in extrusion processed (floating) diets on the growth of juvenile rainbow trout (Salmo gairdneri). Aquaculture, 35, 201-210. doi: https://doi.org/10.1016/0044-8486(83)90091-1

Hughes, S. G., (1990). Use of triticale as a replacement for wheat middlings in diets for Atlantic salmon. Aquaculture, 90(2), 173-178. doi: https://doi.org/10.1016/0044-8486(90)90339-O

Kurtoğlu, A., Sevgili, H., Oiakawa, M., (2019). Effects of different feeding frequencies on growth performance and feed consumption in juvenile turbot (Scophthalmus maximus Linnaeus, 1758). Acta Aquatica Turcica, 15(3), 404-410. doi: https://doi.org/10.22392/actaquatr.540268

McGoogan, B.B., Reigh, R.C., (1996). Apparent digestibility of selected ingredients in red drum (Sciaenops ocellatus) diets. Aquaculture, 141, 233$244 . \quad$ doi: https://doi.org/10.1016/0044$\underline{8486(95) 01217-6}$

Nagel, F., von Danwitz, A., Tusche, K., Kroeckel, S., van Bussel, C.G., Schlachter, M., Adem, H., Tressel, R.-P., Schulz, C., (2012). Nutritional evaluation of rapeseed protein isolate as fish meal substitute for juvenile turbot (Psetta maxima L.) - Impact on growth performance, body composition, nutrient digestibility and blood physiology. Aquaculture, 356, 357-364. doi: https://doi.org/10.1016/j.aquaculture.2012.04.045

NRC, (2011). NRC. Nutrient requirements of fish and shrimp. Washington, DC: National Research Council of the National Academies.
Pessini, J. E., Sanchez, M. S. S., Rodrigues, M. L., Boscolo, W. R., Bittencourt, F., Signor, A., (2019). Wheat middling in diets supplemented with phytase for silver catfish juveniles. Medicina Veterinária (UFRPE), 13(3), 464-473. doi: https://doi.org/10.26605/medvet-v13n3-3313

Rawles, S.D., Gatlin, D.M., (2000). Nutrient digestibility of common feedstuffs in extruded diets for sunshine bass Morone chrysops $\propto \times$ M. saxatilis $\widehat{O}$. Journal of the World Aquaculture Society, 31, 570-579. doi: https://doi.org/10.1111/j.1749-7345.2000.tb00906.x

Satoh, S., Tabata, K., Izume, K., Takeuchi, T., Watanabe, T., (1987). Effect of dietary tricalcium phosphate on availability of zinc to rainbow trout [Salmo gairdnerii]. Bulletin of the Japanese Society of Scientific Fisheries (Japan), 53, 1199-1205. doi: https://doi.org/10.2331/suisan.53.1199

Sevgili, H., Kurtoğlu, A., Oikawa, M., Aksoy, A., Kocakaya, S., Öztürk, E., Uysal, R., Gündüz Oruç, H., (2015a). A combination of corn gluten and soybean meal as a substitute for fishmeal in diets of turbot (Scophthalmus maximus Linnaeus, 1758) in brackish water. Journal of Applied Ichthyology, 31(2), 355-361. doi: https://doi.org/10.1111/jai.12683

Sevgili, H., Kurtoğlu, A., Oikawa, M., Fedekar, D., Emre, Y., Takeno, N., (2015b). Evaluation of nutritional values of selected commercial fish meal sources in turbot (Psetta maxima) diets. Aquaculture Research, 46, 2332-2343. doi: https://doi.org/10.1111/are.12389

Sugiura, S.H., Dong, F.M., Rathbone, C.K., Hardy, R.W., (1998). Apparent protein digestibility and mineral availabilities in various feed ingredients for salmonid feeds. Aquaculture, 159, 177-202. doi: https://doi.org/10.1016/S0044-8486(97)00177-4

Uyan, O., Koshio, S., Ishikawa, M., Uyan, S., Ren, T., Yokoyama, S., Komilus, C.F., Michael, F.R., (2007). Effects of dietary phosphorus and phospholipid level on growth, and phosphorus deficiency signs in juvenile Japanese flounder, Paralichthys olivaceus. Aquaculture, 267, 44-54. doi: https://doi.org/10.1016/j.aquaculture.2007.01.020

van Bussel, C. G., Mahlmann, L., Kroeckel, S., Schroeder, J. P., Schulz, C., (2013). The effect of high ortho-phosphate water levels on growth, feed intake, nutrient utilization and health status of juvenile turbot (Psetta maxima) reared in intensive recirculating aquaculture systems (RAS). Aquacultural Engineering, 57, 63-70. doi: https://doi.org/10.1016/j.aquaeng.2013.08.003 
Vidal, L.V.O., Xavier, T.O., Moura, L.B.d., Michelato, M., Martins, E.N., Furuya, W.M., (2017). Apparent digestibility of wheat and coproducts in extruded diets for the Nile tilapia, Oreochromis niloticus. Revista Brasileira de Saúde e Produção Animal, 18, 479-491. doi: $\quad$ https://doi.org/10.1590/s1519$\underline{99402017000300008}$

Wang, X., Choi, S., Park, S., Yoo, G., Kim, K., Kang, J.-C., Bai, S.C., (2005). Optimum dietary phosphorus level of juvenile Japanese flounder Paralichthys olivaceus reared in the recirculating system. Fisheries Science, $\quad 71, \quad 168-173 . \quad$ doi: https://doi.org/10.1111/j.1444-2906.2005.00944.x 